\title{
ANALYSIS OF RECEPTION AND CRITICAL DISCOURSE OF THE EYECANDY RUBRIC ON ADULT MEN MAGAZINE
}

\author{
Citra Eka PUTRI ${ }^{*}$, Radja Erland HAMZAH ${ }^{2}$ and Yarsita Dwiokta PUTRI ${ }^{3}$ \\ ${ }^{1,2}$ Department of Communications, University of Prof. Dr. Moestopo (Beragama), Jakarta, Indonesia \\ ${ }^{3}$ Postgraduate, University of Prof. Dr. Moestopo (Beragama), Jakarta, Indonesia \\ *ekaputricitra8@gmail.com
}

\begin{abstract}
Eyecandy is a rubrik in the adult men's magazine "Popular", featuring sensual content from many of its models, and what happens when the rubric is interpreted critically by female readers. When the workers and editors at the magazine are dominated by men who have full power in determining the value of women in a society's social life through the discourse that appears in it. Meanwhile, women are positioned as objects that do not have the power to determine these values. The purpose of this study is how audience reception interprets the perspective of critical discourse on the text wrapped in the pose of a woman's body shape in the eyecandy rubric in the December 2017 issue of "Popular" magazine. This research uses a qualitative approach with the study method of critical discourse reception by Norman Fairclough's model. The results of the research show that the text in the eyecandy rubric gives a sensual meaning, where that meaning still binds women as the main sexual commodity that is traded in the form of visual objects. The text is only a complementary narrative of the many sensual poses of female models. The production in the process of making this text is dominated by men, where men seem to understand very well how a text and images are used as representations of attractiveness that is able to attract their people, thus proving that women are objects of sexuality where the media constructs according to the wishes of their male readers.
\end{abstract}

\section{Keywords: Reception Studies, Critical Discourse, Adult Men’s Magazines, “Popular” Magazines}

\section{BACKGROUND}

Mass media is a tool to convey information, thoughts, and ideas to a wide audience (Cenderamata \& Darmayanti, 2019). Competition in the mass media industry makes magazines in Indonesia compete to provide new innovations to attract the attention of many audiences. But sometimes, magazines have difficulty in choosing the right innovation to attract the attention of the audience. Magazines as a medium of mass communication, among others, choose to insert entertainment which is included in an article column that aims to attract the attention of readers. Mass media and the internet are used as a means of disseminating information (Gumilar \& Zulfan, 2014). Mass media has advantages that other types of communication do not have because they are able to overcome the barriers of space and time. The mass media are even able to spread messages in a limited time almost instantly. (Nurudin, 2007).

This is marked by the emergence of various print and electronic mass media, the number of which is increasing day by day. Online media or electronic media have become part of modern human life today (Nurkinan, 2017). Today's mass media in Indonesia are indeed more competitive in seeking profit, and not even a few owners of strong capital take part in mass media companies. This condition makes members of the press conglomerate no longer have 'independence' in determining themselves. Along with major changes in Indonesia, with the reforms, the trauma about the ban could disappear, because now freedom of the press in Indonesia is one of the rights of the public. Press freedom and democracy are two sides of a coin, inseparable and interrelated with each other, where a large system will affect the sub-systems within it (Rahmi, 2019).

The relationship between women and the mass media in public literature is very close. Women are still considered as second-class humans who are under the superiority of men (Hamdani, 2017). Women are presented as 'selling tools' and 'objects of sale'. As a 'selling tool' women appear in advertisements and marketing promotions. Women are also used as sweetener objects in the mass media (Miftakhur, 2018). And as 'objects of sale', women appear as sexual objects, pornographic materials, and victims of crime (violence). Women in relation to the print mass media are so closely related to women's problems as a whole in a patriarchal society or culture such as in Indonesia.

Patriarchy is a concept that refers to everything that is fundamentally and universally accepted as the domination of men, or a culture that is more concerned with the interests of men than the interests of women. Or it can be interpreted that all aspects of society are based on the interests of men. This is indicated by the large number of men occupying roles in the public sector and women in the domestic sector. The nature of women who are given the natural talent to conceive, give birth, and breastfeed, makes them identified as weak, desireless, emotional, and passive human beings. Then, it becomes something common if a man should occupy a public space where he has the ability to power.

Media is a means of control in society which is generally associated with masculinity, so it is not a problem if men dominate. In the end, the media shape their own social reality. Gender issues, especially women and sexuality, are spices that are considered important by capitalists (Juditha, 2015). This finally leads to the conclusion that it is not a problem if there is a mass media, be it a yellow newspaper or not, which attracts its readers by providing news with entertainment content about women without containing an element of empowerment. Judging from the content and form, it is clear that the 
magazine "Popular" is an adult men's magazine with the upper middle class segmentation. However, the number of words, pictures about sexuality, especially about women, makes anyone who reads it (especially men) feel sad, sorry. Unfortunately, these words are always associated with women who tend to be objects, insults, and jokes in their reporting.

In this study, the author wants to examine how the construction of women in a mass media, especially adult men's magazines. This study focuses on how women are depicted in a rubric that is displayed by the magazine itself, this is because women are often depicted through the perspective or point of view of men so that this creates a gender bias. How about when the rubric is interpreted critically by female readers without the influence of male domination in it. Because we know that the dominance of workers and editors in the magazine is dominated by men. Therefore, the problem raised in this study is how women in the eyecandy rubric of the magazine for adult men "Popular", which still have not touched the fundamental problem of women's position, are taken from the perspective of critical discourse. When talking about women, it is important to distinguish between sex and gender, because there are big differences between the two. When talking about sex, it is necessary to know in advance that sex is a biological thing that functions as a certain gender differentiator in a person. Biologically it is not interchangeable and is the nature of God. Unlike the case with gender, gender is a difference that appears in men and women seen from existing values and behavior.

Gender can be interpreted as a sociocultural construction that distinguishes a character categorized into masculine or feminist (Mansour Faqih, 2019). Gender differences are actually not a problem, but what happens in real life can lead to gender inequality, especially for women. In the social processes that occur in society, the treatment received by women is considered to tend to lack respect for women. This study focuses on the eyecandy rubric in the "Popular" magazine. This magazine provides a discourse on how the role of women in a city's life in the rubric "eyecandy" December 2017 edition. In the editorial of this edition the dominance of certain parties in it will greatly influence what discourse will be shown. This can happen because the party who is able to dominate something can easily show a meaning to the party or person who has no dominance at all.

Previous research as the basic basis of differentiation in this study is the research entitled "Representation of Women's Sensuality in Ax Advertising (Semiotic study of representation of women's sensuality in ax advertising version of the ax effect on television)". In this study, the representation of femininity on female symbols in Ax Dark advertisements often displays sensual and sexual aspects that tend to lead to negative connotations. The appearance of women in the Ax Dark Temptation advertisement which highlights the sensual and sexual aspects is a contradiction for women who oppose all forms of oppression against women and demand gender equality status. This movement is known as the feminist movement. To analyze the symbols, images and text in the packaging display, a semiotic method is needed, because the field of semiotics studies the symbolic function and guides the reader in order to capture the message contained therein. In other words, semiotics has a role to "introduce" the codes on the packaging display. This research uses the semiotic view of Charles Sanders Peirce who uses a triangle of meaning (tricotomy) to interpret the symbols contained in the packaging display by linking the sign, object, and interpretant (Ari, 2011).

The second previous research, namely research entitled "Gender and Sexuality in Mass Media Construction". In the study, it was explained that television shows were found in various kinds of pop culture, from advertisements to films. And in these shows, gender issues, especially women and sexuality, become spices that are considered important by capitalists. The goal is none other than so that these impressions have a place in the hearts of the audience. The mass media should not only raise the issue of stereotyping with the dominance of men and women as sex objects. The media should help women to open their horizons and change the image of women themselves. At least it is balanced in describing the figures of women and men with no gender bias (Juditha, 2015).

In contrast to the two previous studies, this study explains how critical discourse analysis is on the eyecandy rubric in the December 2017 edition of the adult men's magazine. The eyecandy rubric itself is a rubric that has several sub-themes such as eyecandy Rising star, eyecandy on the cover, eyecandy Miss Popular and eyecandy. in myroom, where the eyecandy rubric is the most sought after by male readers because it displays sensual content from many models. Therefore, this rubric becomes interesting to study, then what if the rubric is interpreted critically by female readers without the influence of male domination in it. Because we know that the dominance of workers and editors in the magazine is dominated by men. Thus, it is men who have full power in determining values about women in a social life of urban society through the discourses that appear in the magazine. Meanwhile, women in this magazine are positioned as objects who do not have any power in determining the values that are written into text and images. The researcher wants to dig deeper into the perspective of female readers in the eyecandy rubric in the magazine. How does audience reception interpret the perspective of critical discourse on text wrapped in the pose of a woman's body shape in the eyecandy rubric in the December 2017 issue of the adult men's magazine "Popular".

\section{METHODS}

This research was conducted using a qualitative approach with a scalpel of critical discourse analysis 
developed by Norman Fairclough. This qualitative approach focuses on the general principles that underlie the realization of a meaning from social phenomena in society (Bungin, 2010). This research is presented in the form of a description of the words (description), therefore a descriptive qualitative research method is used. The descriptive method itself has the meaning of research designed to collect, analyze, and present real information data, this research can provide a clear picture of the object under study to draw conclusions from the object of research.

Qualitative research is an interpretive research that uses interpretation and many methods in examining research problems in order to obtain a comprehensive understanding of the issues under study. Meanwhile, as a scalpel is critical discourse analysis (CDA) developed by Norman Fairclough. Fairclough builds an analysis of a discourse analysis model that contributes to social and cultural analysis, so that his analysis combines the tradition of textual analysis with the wider context of society (Halim, 2013).

In addition, researchers use the reception analysis method which is a new tradition in audience studies in addition to studies on effects, uses and gratifications, and cultural studies. Broadly speaking, in reception analysis, the meaning of the text does not lie in the text itself. The audience does not find meaning in the text but in their interaction with the text. Reception analysis also involves contextual factors that influence the audience's interpretation of media texts, such as identity, social background, and perception. Because it is a reception analysis that focuses on receiving messages and meaning, audiences are seen as having the power to understand media messages. The media are no longer considered to be in a stronger position than the audience. Reception analysis usually uses an ethnographic approach in its method (McQuail, 2011). This study uses a critical paradigm that has a number of assumptions about how research should be carried out, and how news texts should be analyzed.

In this study, the data source comes from Popular magazine, similar previous research and literature review as a source of information. The subject of this research is the audience who has read the magazine "Popular" No. 359 December 2017 issue who is domiciled in Jakarta. The informants in this study were five women who had read the "Popular" magazine.

\section{RESULTS AND DISCUSSION}

\section{Norman Fairclough's Critical Discourse Analysis}

Fairclough divides critical discourse analysis into three dimensions, (Sobur, 2012), namely: First, texts are analyzed linguistically, by looking at vocabulary, semantics, and sentence structure. Not only that, the text also includes coherence and cohesiveness, how the words or sentences are combined to form understanding. In the text it usually refers to a certain ideological content of a media. In analyzing the text, the writer uses reception analysis technique, the meaning of the text does not lie in the text itself. The audience does not find meaning in the text but in their interaction with the text. Reception analysis also involves contextual factors that influence the audience's interpretation of media texts, such as identity, social background, and perception. Because it is a reception analysis that focuses on receiving messages and meaning, audiences are seen as having the power to understand media messages. Second, Discourse Practice is a dimension related to the process of producing and consuming texts. A news text is basically produced through different text production processes, such as how work patterns, work charts, and routines produce news. While the process of consuming news texts is produced personally when someone consumes texts or collectively. In this case, the author conducted in-depth interviews with gatekeepers, as well as journalists in order to get maximum results. Third, Sociocultural Practice Dimensions related to contexts outside the text, namely their relationship with society or certain cultures and politics. In this case the author analyzes by conducting a literature study or literature study, as well as conducting interviews with female figures. This is intended to obtain opinions on different views (Eriyanto, 2011).

Table 1. Critical discourse analysis of Norman Fairclough's model in the eyecandy rubric of Popular adult men's magazine

\begin{tabular}{|c|c|c|c|c|}
\hline No. & Rubric & Text & Discourse Practice & Sociocultural Practice \\
\hline 1 & $\begin{array}{l}\text { Eyecandy } \\
\text { Rising Star }\end{array}$ & $\begin{array}{l}\text { The text that stands out in the title of this } \\
\text { page is "Have Fun With Sashimi Girl" } \\
\text { It is interpreted that women are a meal that } \\
\text { can certainly be enjoyed by men, plus the } \\
\text { pose in the picture makes the meaning even } \\
\text { stronger that having fun here means that } \\
\text { women can become objects to have fun with } \\
\text { a negative connotation. }\end{array}$ & $\begin{array}{l}\text { The production in the } \\
\text { process of making this text } \\
\text { is a woman who knows very } \\
\text { well what makes men happy, } \\
\text { both with poses and text in } \\
\text { the form of seductive words } \\
\text { and make male readers } \\
\text { imagine wildly. }\end{array}$ & $\begin{array}{l}\text { The female readers think that the text } \\
\text { in this rubric is made as naughty as } \\
\text { possible so that the readers who are } \\
\text { dominated by men feel tempted and } \\
\text { can fantasize both with the text and the } \\
\text { image, this representation for women } \\
\text { is a form of exploitation of the female } \\
\text { body. }\end{array}$ \\
\hline 2 & $\begin{array}{l}\text { Eyecandy On } \\
\text { the Cover }\end{array}$ & $\begin{array}{l}\text { The text that stands out in this rubric is the } \\
\text { question that the editor of a popular magazine } \\
\text { gives to the model regarding the size of the } \\
\text { male genitalia with his wallet, coupled with } \\
\text { the model's sensual pose with a slightly } \\
\text { naughty smile, as if it can be interpreted that } \\
\text { this text represents women who are given the } \\
\text { choice to choose between material or sexual } \\
\text { satisfaction possessed by men. }\end{array}$ & $\begin{array}{l}\text { The making of text and images } \\
\text { in this rubric is carried out by } \\
\text { a male editor who understands } \\
\text { how text and images are } \\
\text { used as representations of } \\
\text { attractiveness that can attract } \\
\text { men. }\end{array}$ & $\begin{array}{l}\text { The female readers feel that the questions } \\
\text { in this text rubric use women as the main } \\
\text { commodity of selling objects in the media, } \\
\text { where questions about women are still } \\
\text { associated with sexuality and material } \\
\text { things, where these two things seem to } \\
\text { project that a woman's happiness factor } \\
\text { is only related to money and sexual } \\
\text { satisfaction.. }\end{array}$ \\
\hline
\end{tabular}




\begin{tabular}{|c|c|c|c|c|}
\hline No. & Rubric & Text & Discourse Practice & Sociocultural Practice \\
\hline 3 & $\begin{array}{l}\text { Eyecandy Miss } \\
\text { Popular }\end{array}$ & $\begin{array}{l}\text { The text in the rubric "The charm of } \\
\text { women with melodious voices" when } \\
\text { looking at the poses and pictures that } \\
\text { are displayed with text seems to blur } \\
\text { the melodious side of the model's voice, } \\
\text { but instead will focus on the model's } \\
\text { sexy clothes so that men who watch will } \\
\text { definitely be more fascinated by her } \\
\text { sensual body than her voice. }\end{array}$ & $\begin{array}{l}\text { The production in the } \\
\text { process of making this text } \\
\text { is a woman, who knows } \\
\text { very well what makes men } \\
\text { happy, both with poses and } \\
\text { text in the form of words } \\
\text { that seduce and make } \\
\text { male readers have wild } \\
\text { imaginations. }\end{array}$ & $\begin{array}{l}\text { The female readers feel that the clothes } \\
\text { used by these women actually fascinate } \\
\text { men more than their abilities as a singer, } \\
\text { on the side of this text emphasizing the } \\
\text { word "charm of Indonesian women" does } \\
\text { not represent Indonesian women in general } \\
\text { but is more connoted with the sexy pose of } \\
\text { the woman. the female model, that women } \\
\text { are still a sexual object that is widely used } \\
\text { by the media as a profitable product. }\end{array}$ \\
\hline 4 & $\begin{array}{l}\text { Eyecandy In } \\
\text { My Room }\end{array}$ & $\begin{array}{l}\text { The text in this rubric is a sexy } \\
\text { investigator "I can immediately get } \\
\text { aroused when I feel I have feelings for that } \\
\text { guy". Where textually this emphasizes that } \\
\text { a woman's passion can come as quickly } \\
\text { as feelings with the opposite sex, the text } \\
\text { in this rubric is used as a subtitle where } \\
\text { it is interpreted that women's passion is } \\
\text { a context that is easily actualized by men } \\
\text { who have an attractive appearance, of } \\
\text { course the passion that is discussed in the } \\
\text { text has the connotation of sexual arousal, } \\
\text { plus the woman's pose is seen wearing a } \\
\text { mini nightgown. }\end{array}$ & $\begin{array}{l}\text { The making of text and } \\
\text { images in this rubric is } \\
\text { carried out by a male } \\
\text { editor who understands } \\
\text { how text and images are } \\
\text { used as representations of } \\
\text { attractiveness that can attract } \\
\text { men. }\end{array}$ & $\begin{array}{l}\text { The female readers represent that the text } \\
\text { in this rubric seems to generalize that all } \\
\text { women have easy sexual arousal with } \\
\text { the opposite sex, even though in reality } \\
\text { that passion comes from many factors, } \\
\text { one of which is the existence of women's } \\
\text { social penetration as measured by the } \\
\text { depth of communication, intensity and } \\
\text { openness between men and women, not } \\
\text { only because of feelings alone. Women's } \\
\text { passion is described as easy and cheap to } \\
\text { catch by men, this of course still proves that } \\
\text { women are capable of becoming objects } \\
\text { of sexuality where the media constructs } \\
\text { according to the wishes of the readers.. }\end{array}$ \\
\hline
\end{tabular}

Table 2. Eyecandy rubric for adult men's magazine "Popular"

\begin{tabular}{lll} 
No. & \multicolumn{1}{c}{ Rubric } & \multicolumn{1}{c}{ Description } \\
\hline 1 & Eyecandy Rising Star & Eyecandy Rising Star, Female model name: Moski Love, Rubric theme: Have Fun \\
With Sashimi Girl!. Author of the article: Adinda Rachmani. In figure 1 of the Eyecandy \\
Rising Star section, the female model in this section is named Moski Love, one of the \\
finalists of Miss Popular Batch 4 and was given the nickname "Pioneer DJ Hunt" in \\
2015. This section contains a question and answer conversation between article writers \\
Adinda Rachmani and Moski Love regarding daily life, work, and ideal male figure. The \\
background of the pages in this rubric is in accordance with the theme, Have Fun With \\
Sashimi Girl!. Where the model uses a mini dress to make her body as a table filled with \\
sushi sashimi. Then, the model also wears a typical Japanese Kimono with a very open \\
cleavage. Next, the model takes a photo as a waitress in a Japanese restaurant wearing a \\
short white shirt without bottoms and a waitress apron at the waist.
\end{tabular}

(Source: Popular Magazine December 2017 issue)

2 Eyecandy On the Cover

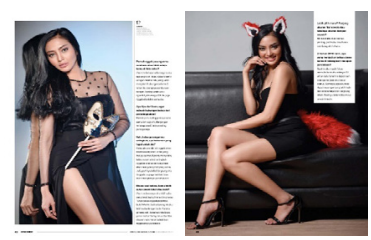

Figure 2. Eyecandy rubric on the cover

(Source: Popular Magazine December 2017 issue)

3 Evecandv Miss Popular

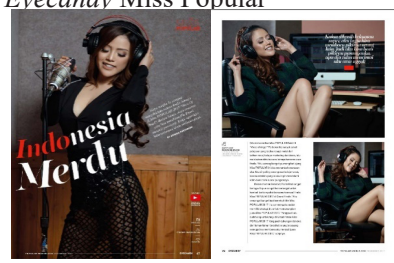

Figure 3. Miss Popular's Eyecandy Rubric.

(Source: December 2017 issue of Popular magazine)

4 Figure 4. Rubrik Eyecandy in my Room

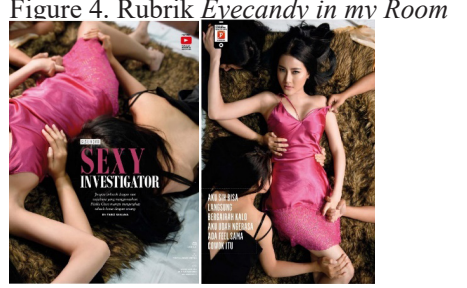

Eyecandy On the Cover, Female model name: Fita Pamela, Rubric theme: Bringing Sexy Back!. Author of the article: Iqbal Fahlevi. In figure 2 of the Eyecandy On the Cover rubric, this female model is named Fita Pamela, besides being a model, Fita is also a DJ who in this issue became the cover of that issue of Popular magazine. This rubric contains a question and answer conversation between article writers and models about daily life, work, sex life and ideal man. The background of the page in this rubric is in accordance with the theme, Bringin Sexy Back, where the model wears all-black mini clothes. An interesting photo is a photo where Fita Pamela is wearing a black mini dress decorated with a fox ear bandana and a red fox fur tail. Fita Pamela is the model on the cover of the popular magazine December 2017 issue which is the source of the research.

Eyecandy Miss Popular, Name of female model: Fla Puteri, Theme of the rubric: Enchantment of Indonesian Women with Sweet Voices, Author of the article: Adinda Rachmani. In figure 3, a female model named Fla Putri is the winner of Miss Popular Batch 5 for the "Voice of Angel" category because of her singing skills. The entire Eyecandy rubric is 20 pages long. Seven pages contain about Fla Putri, one page contains advertisements, and twelve pages contain articles for the finalists of Miss Popular 2017. This rubric contains a question and answer conversation between the article writer and model Fla Puteri regarding her love for the world of music and her readiness to advance to the Miss Popular 2017 Final. Where the background of this rubric is a music studio complete with loudspeakers, guitar and songbook. The same interesting photo as the previous eyecandy section of On The Cover is a photo where Fla Puteri also wears an all black outfit decorated with a fox ear bandana and a red fox fur tail.

Fourth, Eyecandy In My Room, Name of female model: Sisilia Chan, Theme of the rubric: Sexy Investigator, Author of the article: Fariz Sanjaya. In Figure 4 of the Eyecandy In My Room rubric, the female model in this section is named Sisilia Chan. This rubric contains a question and answer conversation between the authors of the article Fariz Sanjaya and Sisilia about her liking for traveling to the mountains and questions about her ideal man. The background of the page in this rubric is in accordance with the theme, namely Sexy Investigator. Where the model takes pictures as if she is a journalist at the office but still wears clothes with an open cleavage and thigh-high cleavage. 
Eyecandy rubric for adult men's magazine "Popular"

The total pages in Popular magazine No.359 December 2017 were 138 pages and the eyecandy rubric filled 46 pages. One third of the magazine's contents are the eyecandy rubric which is divided into four sections, namely eyecandy rising star, eyecandy on the cover, eyecandy miss Popular and eyecandy In My Room. It can be said that the Eyecandy rubric is the main highlight of this magazine. When viewing the cover of the magazine, the reader is presented with the appearance of a beautiful adult woman with sensual poses but still wearing clothes that cover the sensitive parts of women. The researcher continued to read the table of contents which was only written on one page. Consisting of 2 columns, the left column only lists pages of 2 rubrics (eyecandy and topgun) and the right column contains photos of women with the Eyecandy rubric on page 110 . From the table of contents, it can be seen that the pages are written for only two rubrics, namely Eyecandy and Top Gun. Eyecandy starts from page 16 and Top Gun starts from page 30 . Then in the right column the table of contents only shows photos of women in the Eyecandy rubric on page 110. The Eyecandy rubric, is divided into four parts, namely rising stars (pages 1724), on the cover (page 38-48), Miss Popular (page 66-85), In My Room (page 110-116).

\section{Analysis of Eyecandy Rubric Reception in Popular adult men's magazine}

McQuail classifies reception research as a modern cultural study that falls within the realm of a behavioral structuralist approach. Some related to focus in terms of reception analysis (McQuail, 2011), including: First, media texts must be read based on audience perceptions. Where the perception is uncertain and unpredictable. The audience constructs meaning freely and according to their respective backgrounds. In the reception analysis in this study, five resource persons gave perceptions that they were constructed by several backgrounds, such as housewives, government officials, female students, entrepreneurs and private employees. Perceptions given by resource persons with backgrounds of housewives and female students are considered by researchers to be more critical than career women because their thoughts are more open minded to the world of women in media construction. The focus of reception analysis is the process of using or interpreting media. The essence of this analysis is the processes of how the audience reads, understands, interprets media texts and in the end the results of the process will show the forms of audience reception of the media presented. In this study, five resource persons were able to understand the text and images on the media based on their analysis and understanding and experience. The results of the interview showed that some of the interviewees felt that the media used in this sexual-themed content was in place, namely the adult men's special magazine, but most of the interviewees said that in fact the media constructs women as sexual objects because there is a market, namely men who really likes the sensuality of women so that women are used as the main commodity of sexual products and the wild imagination of their readers.

The use of media is part of the social system in interpretive communities. The meaning of media is used by audiences to share meaning with others and their environment. The media used in this study is an adult men's magazine in Indonesia, when the media constructs women according to market tastes, it can be said that the media follows the will of their audience, especially on content with sexual themes, it is clear that the phenomenon of women as a commodity object of sexuality in the media can It can be interpreted that the media studies what the market tastes like, it can also be interpreted that the audience has dominant control over the dominance of the media. Audiences as interpretive communities have a role in the formation of discourse and frameworks in the meaning of media in their environment. The audience cannot be said to be passive and cannot be said to be equal or equal. Although there will be some more active and experienced audiences. They read, understand and interpret freely according to their respective sociocultural backgrounds. This research can be studied using qualitative and in-depth methods by considering the content, reception behavior and context of both. The description above can be concluded that reception analysis views the audience as part of the interpretive communism being active in interpreting media messages. Audiences don't just take media messages. The audience also has their own background and experience that can influence the process of meaning. The audience has the opportunity to be free and open in interpreting the text in their own way.

\section{CONCLUSION}

Based on the results of the study, the conclusions obtained were first, audiences construct meaning freely and according to their respective backgrounds. In the reception analysis in this study, five resource persons gave perceptions that they were constructed by several backgrounds, such as housewives, government officials, female students, entrepreneurs and private employees. The perception given by resource persons who have a background of housewives and female students is considered by researchers to be more critical than career women because their thoughts are more open minded to the world of women in media construction. Second, the essence of this analysis is the processes of how the audience reads, understands, interprets media texts and in the end the results of the process will show the forms of audience reception of the media presented. In this case, the resource person is able to understand the text and images on the media based on their analysis and understanding and experience. The media used in this sexual-themed content is in place, namely in adult men's 
special magazines, the media constructs women as sexual objects because there is a market, namely men who really like the sensuality of women, so that women are used as the main commodity of products. sexuality and wild imagination of the readers. Third, the use of media is part of the social system in interpretive communities. When the media constructs women according to market tastes, it can be said that the media follows the wishes of their readers, it is clear that the phenomenon of women as a commodity object of sexuality in the media can be interpreted that the media studies what the market tastes like, it can also be interpreted that the audience has dominant control over domination. the media.

\section{REFERENCES}

Ari, D. R. (2011). IKLAN AXE ( Studi semiotik representasi sensualitas perempuan dalam iklan axe versi axe effect di televisi ). 1-107. http://eprints.upnjatim. ac.id/5294/1/file1.pdf

Bungin, B. (2010). Penelitian Kualitatif. Kencana Prenada Media Group.

Cenderamata, R. C., \& Darmayanti, N. (2019). Analisis Wacana Kritis Fairclough Pada Pemberitaan Selebriti Di Media Daring. Jurnal Literasi, 3(1), 1-8. https:// doi.org/http://dx.doi.org/10.25157/literasi.v3i1.1736

Croteau, D. \& W. H. (2003). Media/Society: Industry, Images, and Audiences (3rd ed.). Pine Forge Press. https://books.google.co.id/s?id=UkHMl0uhhZYC\& printsec $=$ copyright $\& \mathrm{hl}=\mathrm{id} \# \mathrm{v}=$ onepage $\& \mathrm{q} \& \mathrm{f}=$ false

Eriyanto. (2011). Analisis Wacana; Pengantar Analisis Teks Media. LKiS.

Gumilar, G., \& Zulfan, I. (2014). Penggunaan Media Massa dan Internet sebagai Sarana Penyampaian Informasi dan Promosi oleh Pengelola Industri Kecil dan Menengah di Bandung. Jurnal Kajian Komunikasi, 2(1), 85-92. https://doi.org/10.24198/jkk.v2i1.6054

Halim, S. (2013). Postkomodifikasi Media: Analisis Media Televisi dengan Teori Kritis dan Cultural Studies. Yogyakarta: Jalasutra.
Hamdani, A. (2017). Eksploitasi Perempuan di Media Massa Perspektif Al Qur'an. Harkat: Media Komunikasi Islam Tentang Gender Dan Anak, Vol. 12(2), 104-115. http://journal.uinjkt.ac.id/index.php/ psga/article/view/7720/4295

Jensen, Klaus Bruhn; Jankowski, N. W. (2002). A Handbook of Qualitative Methodologies for Mass Communication Research. Routledge.

Juditha, C. (2015). Gender dan Seksualitas dalam Konstruksi Media Massa. Jurnal Simbolika: Reserch and Learning in Communication Study, 1(1), 6-14. https:// doi.org/https://doi.org/10.31289/simbollika.vli1.45

Mansour Faqih. (2019). Studi Analisis Gender Mansour Fakih. https://digilib.uin-suka.ac.id/id/ eprint/35013/1/14510018_BAB-1_IV-atau-V_ DAFTAR-PUSTAKA.pdf

McQuail, D. (2011). Teori Komunikasi Massa Mcquail Buku Dua /Denis McQuail (1st ed.). Salemba Humanika. http://opac.ut.ac.id/detail-opac?id=33184

Miftakhur, D. R. (2018). Perempuan dalam Bisnis Media Massa (Studi Pada Perempuan di Televisi swasta Lokal Surabaya dalam Perspektif Gender). Jurnal S1 Sosiologi Universitas Airlangga, 3(2), 1-20.

Nurkinan. (2017). Dampak Media Online Terhadap Perkembangan Media Konvensional. Jurnal Politikom Indonesiana, 2(2), 28-42. https://journal. unsika.ac.id/index.php/politikomindonesiana/article/ view/962

Oliver Boyd, Barrett; Chris, N. (1995). Approaches to media : a reader. St. Martin's Pres. https://www. worldcat.org/title/approaches-to-media-a-reader/ oclc/32510027

Rahmi. (2019). Kebebasan Pers Dan Demokrasi di Indonesia. Jurnal Komunikasi Dan Kebudayaan, 6(1), 41-57. http://komunikasistisip.ejournal.web.id/ index.php/komunikasistisip/article/view/194

Sobur, A. (2012). Analisis Teks Media: Suatu Pengantar Untuk Analisis Wacana, Analisis Semiotik, dan Analisis Framing. Remaja Rosdakarya. 